HETEROCYCLES, Vol. 98, No. 9, 2019, pp. 1251 - 1257. @ 2019 The Japan Institute of Heterocyclic Chemistry Received, 18th August, 2019, Accepted, 13rd September, 2019, Published online, 1st October, 2019 DOI: $10.3987 / C O M-19-14149$

\title{
A NEW $\gamma$-BUTENOLIDE GLYCOSIDE FROM THE ROOT OF STYPHNOLOBIUM JAPONICUM
}

\section{Takahiro Utsumi, Ryuichiro Suzuki,* Hitoshi Kamauchi, Sae Misawa, Masashi Kitamura, Yoshiaki Sugita, and Yoshiaki Shirataki}

\author{
Department of Pharmaceutical Sciences, Faculty of Pharmacy and Pharmaceutical \\ Sciences, Josai University; 1-1 Keyakidai, Sakado, Saitama 350-0295, Japan; \\ E-mail: ryu_suzu@josai.ac.jp
}

\begin{abstract}
A new $\gamma$-butenolide glycoside, named styphnoloside A (1), was isolated from the root of Styphnolobium japonicum (L.) Schott (= Sophora japonica L.), together with saikoisoflavonoside A (2) and sophoraside A (3). The structure of 1 was characterized as puerol B 2"-O-neohesperidoside based on oneand two-dimensional (1D and 2D) NMR, MS, and electronic circular dichroism (ECD) spectral data. The absolute configuration of the aglycone moiety of $\mathbf{1}$ was assigned by comparing its experimental ECD spectrum with the calculated ECD spectrum.
\end{abstract}

Styphnolobium japonicum (L.) Schott (= Sophora japonica L.) is a deciduous tree belonging to the Leguminosae family and is native to China. The bud, fruit and root are used in crude drugs known as "huai-gen" in Chinese. The dried flowers of S. japonicum are used in traditional Japanese medicine for anti-hemorrhagic, anti-hemostatic, and analgesic effects. ${ }^{1,2}$ There have been few phytochemical investigations of the root of $S$. japonicum to date aside from our previously reported isolation and structural elucidation of several flavonoids ${ }^{3,4}$ and butenolides. ${ }^{5,6}$ In the current paper, we report the isolation, purification, and structure elucidation of a new $\gamma$-butenolide glycoside, styphnoloside A (1), together with two known compounds, saikoisoflavonoside $A^{7}(2)$ and sophoraside $A^{5,6}(3)$, from the root this plant.

The roots were dried, extracted with methanol $(\mathrm{MeOH})$ under reflux, and the organic solvent was removed by vacuum evaporation. The combined $\mathrm{MeOH}$ extract was suspended in water and partitioned with diethyl ether $\left(\mathrm{Et}_{2} \mathrm{O}\right)$, ethyl acetate (EtOAc) and $n$-butanol $(n-\mathrm{BuOH})$ successively to yield the corresponding soluble layers. The $n$-BuOH soluble portion was separated by octadecyl-silyl (ODS) column chromatography into 16 fractions (Fr. 1 to 16). Fr. 2 was further subjected to ODS column 
chromatography to afford 10 fractions (Fr. 2-A to 2-J). Fraction 2-D was purified by reverse phase HPLC to isolate compounds $\mathbf{1}$ and $\mathbf{2}$. Compound $\mathbf{3}$ was isolated from Fr. 2-E by HPLC purification using an ODS column (Figure 1).

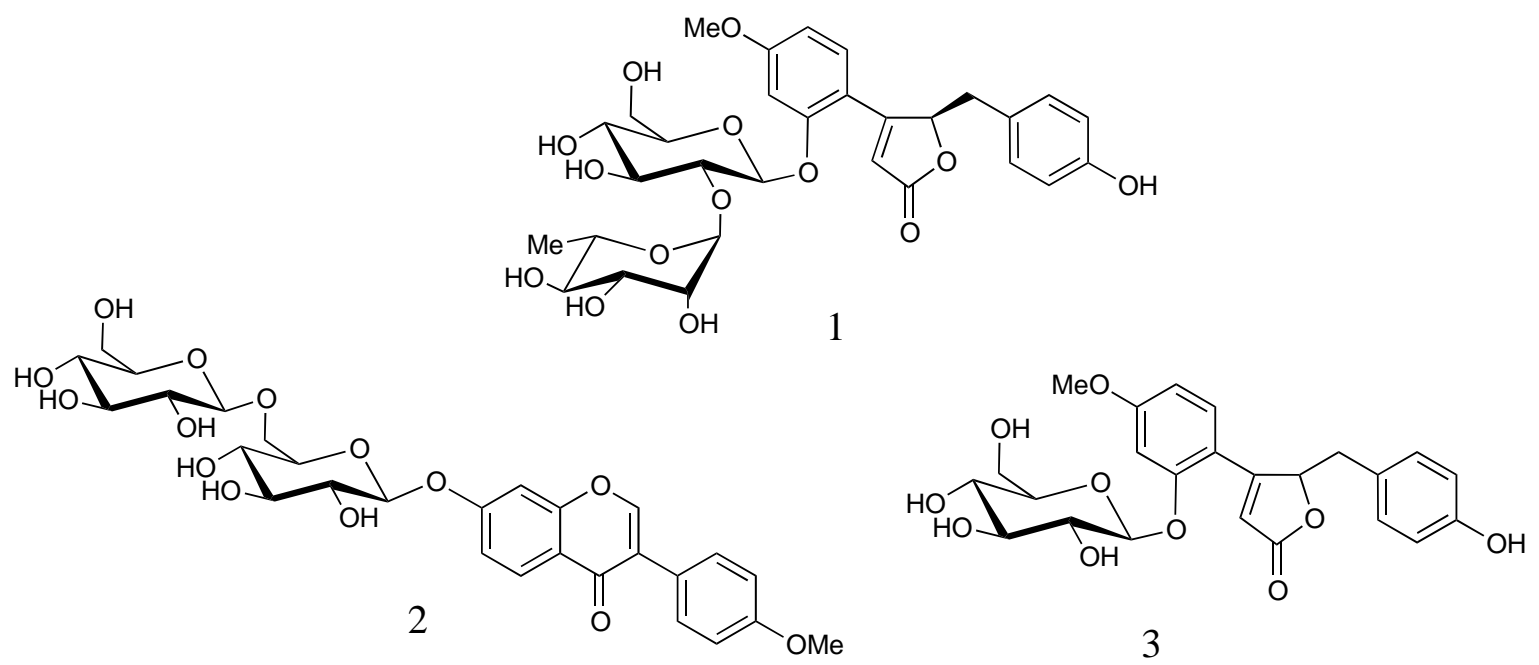

Figure 1. Structure of compounds 1, 2, and $\mathbf{3}$ isolated from the root of $S$. japonicum

Compound 1 was obtained as a pale yellow amorphous, $[\alpha]_{\mathrm{D}}{ }^{25}-145.8$ (c $\left.0.3, \mathrm{MeOH}\right)$. The molecular formula of 1 was determined to be $\mathrm{C}_{30} \mathrm{H}_{36} \mathrm{O}_{14}$ by high-resolution-fast atom bombardment mass spectrometry (HR-FAB-MS) at $m / z$ : $643.2018[\mathrm{M}+\mathrm{Na}]^{+}\left(\right.$calcd for $\mathrm{C}_{30} \mathrm{H}_{36} \mathrm{O}_{14} \mathrm{Na}: 643.2003$ ).

The ${ }^{1} \mathrm{H}-\mathrm{NMR}$ spectrum (Table 1) displayed signals due to a rhamnose methyl at $\delta_{\mathrm{H}} 1.03(3 \mathrm{H}, \mathrm{d}, J=6.2 \mathrm{~Hz})$, two methylene protons at $\delta_{\mathrm{H}} 2.84(1 \mathrm{H}, \mathrm{dd}, J=14.5,5.6 \mathrm{~Hz})$ and $\delta_{\mathrm{H}} 3.23(1 \mathrm{H}, \mathrm{dd}, J=14.5,3.8 \mathrm{~Hz})$, an oxygenated $s p^{3}$ methine proton at $\delta_{\mathrm{H}} 6.05(1 \mathrm{H}$, ddd, $J=5.6,3.8,1.2 \mathrm{~Hz})$, oxygenated glucose methylene protons at $\delta_{\mathrm{H}} 3.63(1 \mathrm{H}, \mathrm{m})$ and $\delta_{\mathrm{H}} 3.82(1 \mathrm{H}, \mathrm{dd}, J=11.8,1.5 \mathrm{~Hz})$, a singlet signal from a methoxy proton at $\delta_{\mathrm{H}} 3.90(3 \mathrm{H}, \mathrm{s})$, two anomeric protons at $\delta_{\mathrm{H}} 5.26(1 \mathrm{H}, \mathrm{d}, J=1.8 \mathrm{~Hz})$ and $\delta_{\mathrm{H}} 5.33(1 \mathrm{H}, \mathrm{d}, J=7.4 \mathrm{~Hz})$, four aromatic protons at $\delta_{\mathrm{H}} 6.36(1 \mathrm{H}, \mathrm{d}, J=1.2 \mathrm{~Hz}), \delta_{\mathrm{H}} 6.80(1 \mathrm{H}, \mathrm{dd}, J=8.8,2.4 \mathrm{~Hz}), \delta_{\mathrm{H}} 6.90(1 \mathrm{H}, \mathrm{d}, J=2.4 \mathrm{~Hz})$ and $\delta_{\mathrm{H}} 7.45(1 \mathrm{H}, \mathrm{d}, J=8.8 \mathrm{~Hz})$, and an AA'BB' type coupling system at $\delta_{\mathrm{H}} 6.85(2 \mathrm{H}, \mathrm{d}, J=8.6 \mathrm{~Hz})$ and $\delta_{\mathrm{H}}$ $6.61(2 \mathrm{H}, \mathrm{d}, J=8.6 \mathrm{~Hz})$.

The ${ }^{13} \mathrm{C}-\mathrm{NMR}$ spectrum (Table 1) of $\mathbf{1}$ showed 29 carbon resonances that were classified by their chemical shift values and heteronuclear single quantum coherence (HSQC) spectrum as: one methoxy carbon $\left(\delta_{\mathrm{C}} 56.5\right)$, eight $s p^{2}$ methine carbons $\left(\delta_{\mathrm{C}} 104.7,110.8,116.0,116.1,132.2,132.2\right)$, six $s p^{2}$ quaternary carbons $\left(\delta_{\mathrm{C}} 127.4,157.5,158.6,165.2,167.0,176.7\right)$, an $s p^{3}$ methine carbon at $\delta_{\mathrm{C}} 85.6$, and an $s p^{3}$ methylene carbon at $\delta_{C} 39.5$. In addition, a glucopyranosyl and a rhamnopyranosyl were inferred by comparisons of the ${ }^{1} \mathrm{H}-\mathrm{NMR}$ and ${ }^{13} \mathrm{C}-\mathrm{NMR}$ data with that in the literature ${ }^{8}$ (rhamnose: $\delta_{\mathrm{C}} 18.2,70.6,72.4$, 72.5, 74.2 and 103.2, and glucose: $\delta_{C} 62.8,71.6,78.6,79.0,81.6$ and 102.3). These NMR spectral data 
are listed in Table 1. Although the carbon signal attributed to C-1" was not observed in MeOH- $d_{4}$, this signal was detected in aqueous acetone- $d_{6}$.

The ${ }^{1} \mathrm{H}$ - and ${ }^{13} \mathrm{C}$-NMR spectroscopic data of 1 were very similar to those of puerol $\mathrm{B}$, ${ }^{6,9}$ except for the chemical shift values of the glucose and rhamnose moieties.

The heteronuclear multiple bond connectivity (HMBC) spectrum exhibited correlations between $\delta_{\mathrm{H}} 2.84$ $(\mathrm{H}-4 \mathrm{a}, \alpha), \delta_{\mathrm{H}} 3.23(\mathrm{H}-4 \mathrm{a}, \beta)$ and $\delta_{\mathrm{C}} 85.6(\mathrm{C}-4), \delta_{\mathrm{C}} 127.4\left(\mathrm{C}-1^{\prime}\right)$ and $\delta_{\mathrm{C}} 132.2\left(\mathrm{C}-2^{\prime} 6^{\prime}\right)$. And long-range correlations between $\delta_{\mathrm{H}} 6.36(\mathrm{H}-2)$ and $\delta_{\mathrm{C}} 176.7(\mathrm{C}-1), \delta_{\mathrm{C}} 85.6(\mathrm{C}-4)$ were observed. Furthermore, the HMBC experiments of indicated connections between $\delta_{\mathrm{H}} 7.45$ (H-6”), $\delta_{\mathrm{C}} 158.6$ (C-2"), $\delta_{\mathrm{C}} 165.2$ (C-4") and $\delta_{\mathrm{C}} 167.0(\mathrm{C}-3)$. A resonance at $\delta_{\mathrm{H}} 3.90$ (-OMe) also correlated with $\delta_{\mathrm{C}} 165.2$ (C-4") in HMBC experiments. These results of HMBC experiments revealed the presence of a puerol B moiety (the aglycone of 1). ${ }^{6,9}$ In addition, the long-range correlations of two anomeric protons at $\delta_{\mathrm{H}} 5.26(\mathrm{H}-\mathrm{R} 1)$ and $\delta_{\mathrm{H}} 5.33(\mathrm{H}-\mathrm{G} 1)$ with $\delta_{\mathrm{C}} 81.6(\mathrm{C}-\mathrm{G} 2)$ and $\delta_{\mathrm{C}} 158.6$ (C-2"), respectively, confirmed the linkage of these sugars (Figure 2).

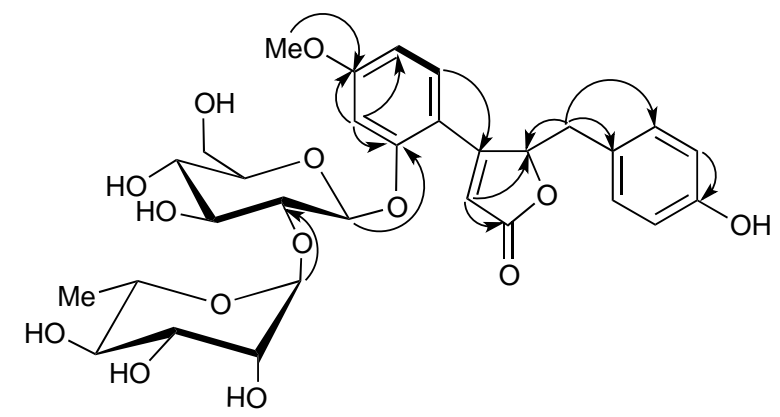

Figure 2. Diagnostically significant long-range correlation of $\mathbf{1}$

The absolute configuration of $\mathbf{1}$ at $\mathrm{C}-4$ was established by comparison of the experimental electronic circular dichroism (ECD) spectrum with that calculated for (-)-puerol B (4, the aglycone moiety of 1). ${ }^{6,9}$ Acid hydrolysis of 1 using $\mathrm{HCl}$ yielded 4. The first negative Cotton effect in the experimental ECD spectrum of 4 was at $285 \mathrm{~nm}$ and the second positive Cotton effect was at $250 \mathrm{~nm}$, consistent with the spectrum calculated for (4R)-puerol B (Figure 3). Therefore, the absolute configuration of C-4 was $R$.

The sugar units liberated by acid hydrolysis of compound $\mathbf{1}$ were identified as D-glucose and L-rhamnose by HPLC analysis of derivatives prepared by reaction with L-cysteine methyl ester and phenyl isothiocyanate according to a previously reported method. ${ }^{10}$ Acid hydrolysis of 1 with $2 \mathrm{~N}-\mathrm{HCl}$ liberated D-glucose and L-rhamnose, and the glucose linkage and chemical shift values of the rhamnose moiety were indicative of $\alpha$. Based on the NMR and acid hydrolysis data, the structure of 1 was determined to be (4R)-3-(2-( $\alpha$-L-rhamnopyranosyl)-( $1 \rightarrow 2)$ - $\beta$-D-glucopyranosyloxy-4-merthoxyphenyl)-4-(4-hydroxybenzyl)but-2-en-4-olide (Figure 1). We named this compound styphnoloside A. Compounds 1, 2, and 3 
were tested for tyrosinase inhibitory activity, $\alpha$-glucosidase inhibitory activity and 1,1-diphenyl-2picrylhydrazyl (DPPH) free radical scavenging activity, in vitro. However, none of them showed significant activities up to a concentration of $1.6 \mathrm{mM}$, respectively.<smiles>COc1ccc(C2=CC(=O)O[C@H]2Cc2ccc(O)cc2)c(O)c1</smiles>

$4 S$<smiles>COc1ccc(C2=CC(=O)O[C@H]2Cc2ccc(O)cc2)c(O)c1</smiles>

$4 R$

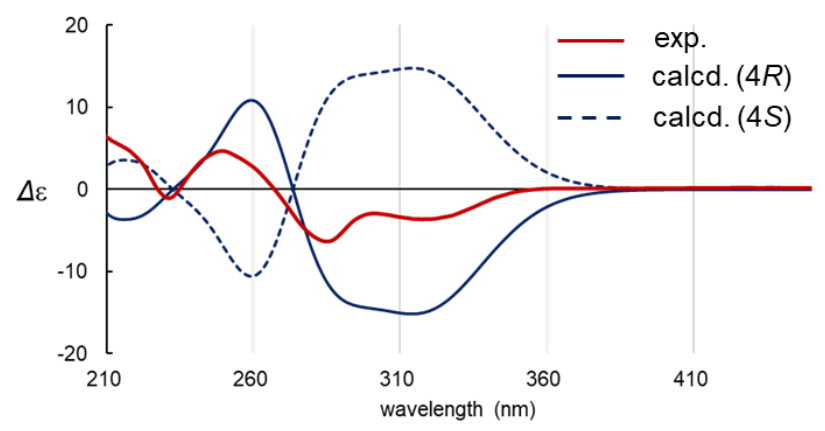

Figure 3. Experimental ECD spectrum of $\mathbf{4}$ and the calculated ECD spectrum of $(3 R)$ - and (3S)-4

Table $1 .{ }^{1} \mathrm{H}$ - and ${ }^{13} \mathrm{C}-\mathrm{NMR}$ spectral data of compound $\mathbf{1}$ in $\mathrm{MeOH}-d_{4}$

\begin{tabular}{|c|c|c|c|c|c|}
\hline Position & $\delta$ H Mult. $(J$ in $\mathrm{Hz})$ & $\delta c$ & \multicolumn{2}{|c|}{ Position $\quad \delta \mathrm{H} \quad$ Mult. $(\mathrm{J}$ in $\mathrm{Hz})$} & \multirow{2}{*}{$\frac{\delta c}{102.3(\mathrm{~d})}$} \\
\hline 1 & - & $176.7(\mathrm{~s})$ & Glc 1 & $5.33(\mathrm{~d}, J=7.4 \mathrm{~Hz}, 1 \mathrm{H})$ & \\
\hline 2 & $6.36(\mathrm{~d}, J=1.2 \mathrm{~Hz}, 1 \mathrm{H})$ & $116.0(\mathrm{~d})$ & 2 & $3.72(\mathrm{~m}, 1 \mathrm{H})$ & $81.6(d)$ \\
\hline 3 & - & $167.0(\mathrm{~s})$ & 3 & $3.63(\mathrm{~m}, 1 \mathrm{H})$ & 79.0 (d) \\
\hline 4 & $6.05(\mathrm{ddd}, J=1 \cdot 2,3 \cdot 8,5.6 \mathrm{~Hz}, 1 \mathrm{H})$ & $85.6(d)$ & 4 & $3.38(\mathrm{~m}, 1 \mathrm{H})$ & $71.6(d)$ \\
\hline $4 a$ & $2.84(\mathrm{dd}, J=5.6,14.5 \mathrm{~Hz}, 1 \mathrm{H})$ & $39.5(\mathrm{t})$ & 5 & $3.38(\mathrm{~m}, 1 \mathrm{H})$ & $78.6(d)$ \\
\hline & $3.23(\mathrm{dd}, J=3.8,14.5 \mathrm{~Hz}, 1 \mathrm{H})$ & & 6 & $3.63(\mathrm{~m}, 1 \mathrm{H})$ & $62.8(\mathrm{t})$ \\
\hline $1^{\prime}$ & - & $127.4(\mathrm{~s})$ & & $3.82(\mathrm{dd}, J=1.5,11.8 \mathrm{~Hz}, 1 \mathrm{H})$ & \\
\hline $2^{\prime}, 6^{\prime}$ & $6.85(\mathrm{~d}, J=8.6 \mathrm{~Hz}, 2 \mathrm{H})$ & $132.2(\mathrm{~d})$ & Rha 1 & $5.26(\mathrm{~d}, J=1.8 \mathrm{~Hz}, 1 \mathrm{H})$ & $103.2(\mathrm{~d})$ \\
\hline $3^{\prime}, 5^{\prime}$ & $6.61(\mathrm{~d}, J=8.6 \mathrm{~Hz}, 2 \mathrm{H})$ & $116.1(\mathrm{~d})$ & 2 & $4.02(\mathrm{dd}, J=1.8,3.3 \mathrm{~Hz}, 1 \mathrm{H})$ & $72.4(d)$ \\
\hline $4^{\prime}$ & - & $157.5(\mathrm{~s})$ & 3 & $3.70(\mathrm{~m}, 1 \mathrm{H})$ & 72.5 (d) \\
\hline $1 "$ & - & N.D.* & 4 & $3.35(\mathrm{~m}, 1 \mathrm{H})$ & 74.2 (d) \\
\hline $2 "$ & - & $158.6(\mathrm{~s})$ & 5 & $3.73(\mathrm{~m}, 1 \mathrm{H})$ & $70.6(d)$ \\
\hline $3 "$ & $6.90(\mathrm{~d}, J=2.4 \mathrm{~Hz}, 1 \mathrm{H})$ & $104.7(d)$ & 6 & $1.03(\mathrm{~d}, J=6.2 \mathrm{~Hz}, 3 \mathrm{H})$ & $18.2(q)$ \\
\hline $4 "$ & - & $165.2(\mathrm{~s})$ & & & \\
\hline $5 "$ & $6.80(\mathrm{dd}, J=8.8,2.4 \mathrm{~Hz}, 1 \mathrm{H})$ & $110.8(\mathrm{~d})$ & & & \\
\hline $6 "$ & $7.45(\mathrm{~d}, J=8.8 \mathrm{~Hz}, 1 \mathrm{H})$ & $132.2(\mathrm{~d})$ & & & \\
\hline $\mathrm{OCH}_{3}$ & $3.90(\mathrm{~s}, 3 \mathrm{H})$ & $56.5(q)$ & & & \\
\hline
\end{tabular}




\section{EXPERIMENTAL}

General Experimental Procedures FAB-MS and HR-FAB-MS were recorded on a JMS-700 (JEOL). ${ }^{1} \mathrm{H}-,{ }^{13} \mathrm{C}$-, and 2D-NMR spectra were recorded at $400 \mathrm{MHz}$ on an Agilent 400-MR NMR system (400 $\mathrm{MHz}$ for ${ }^{1} \mathrm{H}$ and $100 \mathrm{MHz}$ for ${ }^{13} \mathrm{C}$ ) at room temperature. NMR chemical shifts were recorded in ppm with solvent signals as internal references $\left(\delta_{\mathrm{H}} 3.31, \delta_{\mathrm{C}} 49.2\right.$ for MeOH- $d_{4}, \delta_{\mathrm{H}} 2.50, \delta_{\mathrm{C}} 39.5$ for DMSO- $d_{6}$, and $\delta_{\mathrm{H}} 2.05, \delta_{\mathrm{C}} 29.9$ for acetone- $d_{6}$ ). Optical rotations were measured using a P-2300 polarimeter (JASCO, solvent; MeOH). ECD spectra were measured using a J-720WI spectrophotometer (JASCO, solvent; $\mathrm{MeOH})$. UV spectra were obtained on a Shimadzu UV-1280 spectrophotometer.

Plant Material S. japonicum (L.) Schott (= Sophora japonica L.) roots were collected from the botanical garden of Josai University, Saitama, Japan, in May 2017. The plant was authenticated by Dr. Yoshiaki Shirataki. A voucher specimen was deposited at the Laboratory of Pharmacognosy and Natural Medicines, Josai University, as 2017-05-12.

Extraction and Isolation Dried roots of S. japonicum (500 g) were extracted with $\mathrm{MeOH}(1200 \mathrm{~mL})$ for $3 \mathrm{~h}$ under reflux. This extraction was repeated 3 times. The combined $\mathrm{MeOH}$ extract (42 g) was suspended in water and partitioned with $\mathrm{Et}_{2} \mathrm{O}$, EtOAc and $n$ - $\mathrm{BuOH}$ successively to yield the $\mathrm{Et}_{2} \mathrm{O}$ layer (6.1 g), EtOAc layer (9.2 g), $n$-BuOH layer (10.8 g) and $\mathrm{H}_{2} \mathrm{O}$ layer (14.2 g). The $n$-BuOH layer was chromatographed using ODS and gradient elution with a $\mathrm{H}_{2} \mathrm{O}: \mathrm{MeOH}$ mixture $\left(\mathrm{H}_{2} \mathrm{O}: \mathrm{MeOH}=1: 1 \rightarrow 1: 3\right.$ $\rightarrow \mathrm{MeOH}$ ) to afford 16 fractions (Fr. 1 to 16). A portion of Fr. 2 (1.1 g) was chromatographed using ODS and isocratic elution with a $\mathrm{MeCN}: \mathrm{H}_{2} \mathrm{O}$ mixture $\left(\mathrm{MeCN}: \mathrm{H}_{2} \mathrm{O}=1: 3\right)$ to afford 10 fractions (Fr. 2-A to 2-J). Compound 1 (13.8 mg) and compound 2 (13.8 mg) were obtained from Fr. 2-D (141.5 mg) using HPLC and a DOCOSIL column (Senshu Pak, $\phi 10 \times 150 \mathrm{~mm}, \mathrm{MeCN}: \mathrm{H}_{2} \mathrm{O}=1: 4$, isocratic). Compound 3 (10.7 mg) was obtained from Fr. 2-E (30.0 mg) using HPLC and an ODS column (Senshu Pak, $\phi 10 \times$ $150 \mathrm{~mm}, \mathrm{MeCN}: \mathrm{H}_{2} \mathrm{O}=1: 3$, isocratic). Spectroscopic analysis by NMR and MS identified 2 and 3 as saikoisoflavonoside A and sophoraside A, respectively. The spectral data of $\mathbf{2}$ and $\mathbf{3}$ were consistent with the literature values. ${ }^{5-7}$

Styphnoloside A (1), pale yellow, amorphous; molecular formula: $\mathrm{C}_{30} \mathrm{H}_{36} \mathrm{O}_{14} ;[\alpha]_{\mathrm{D}}{ }^{25}-145.8$ (c 0.3 , $\mathrm{MeOH}) ; \mathrm{UV} \lambda \max \mathrm{MeOH} n m(\varepsilon): 286$ (15295), 308 (14909); HR-FAB-MS m/z: $643.2018\left([\mathrm{M}+\mathrm{Na}]^{+}\right)$ (calcd for $\mathrm{C}_{30} \mathrm{H}_{36} \mathrm{O}_{14} \mathrm{Na}$ : 643.2003); $\mathrm{ECD}(\mathrm{MeOH}): 307 \mathrm{~nm}(\Delta \varepsilon-5.5), 287 \mathrm{~nm}(\Delta \varepsilon-7.9), 248 \mathrm{~nm}(\Delta \varepsilon+4.7)$, $231 \mathrm{~nm}(\Delta \varepsilon-0.7) ;{ }^{1} \mathrm{H}-\mathrm{NMR}\left(400 \mathrm{MHz}, \mathrm{MeOH}-d_{4}\right)$ and ${ }^{13} \mathrm{C}-\mathrm{NMR}\left(100 \mathrm{MHz}, \mathrm{MeOH}-d_{4}\right)$ spectral data are listed in Table 1.

Acid Hydrolysis of Compound 1 A solution of $1(12.1 \mathrm{mg})$ in $2 \mathrm{~N}-\mathrm{HCl}(3 \mathrm{~mL})$ was heated at $100{ }^{\circ} \mathrm{C}$ in a screw-capped vial for $6 \mathrm{~h} .4$ was obtained as a powder $(4.2 \mathrm{mg})$. The mixture was neutralized by addition of Dowex $1 \times 8$ (chloride form) and filtered. The reaction mixture was dried in vacuo and 
dissolved in $1 \mathrm{~mL}$ of pyridine containing L-cysteine methyl ester $(5 \mathrm{mg} / \mathrm{mL})$ and reacted at $60{ }^{\circ} \mathrm{C}$ for $1 \mathrm{~h}$. Phenyl isothiocyanate $\left(5 \mathrm{mg}\right.$ ) was added and the mixture was heated at $60{ }^{\circ} \mathrm{C}$ for $1 \mathrm{~h}$, then was directly analyzed by HPLC [Cosmosil 5C18-AR-II $(\phi 4.6 \times 250 \mathrm{~mm}$, Nacalai Tesque): $25 \% \mathrm{MeCN}$ in $50 \mathrm{mM}$ $\mathrm{H}_{3} \mathrm{PO}_{4}$; flow rate $0.8 \mathrm{~mL} / \mathrm{min}$; column temperature $35^{\circ} \mathrm{C}$; detection $250 \mathrm{~nm}$ ]. The $t_{\mathrm{R}}$ of the peak at 16.00 min coincided with that of D-glucose. The $t_{\mathrm{R}}$ of L-rhamnose was $27.33 \mathrm{~min} .{ }^{10}$

(-)-Puerol B (4), brown powder; $[\alpha]_{\mathrm{D}}^{21}-79.4$ (c 0.4, acetone); ECD (MeOH): $317 \mathrm{~nm}(\Delta \varepsilon-3.6), 285 \mathrm{~nm}$ ( $\Delta \varepsilon-6.4), 268 \mathrm{~nm}(\Delta \varepsilon-0.1), 250 \mathrm{~nm}(\Delta \varepsilon+4.7), 231 \mathrm{~nm}(\Delta \varepsilon-1.1)$.

Calculation of ECD Spectra Plausible twenty-four conformations of 4 were manually generated around the dihedral angles C-4-C-3-C-1"'-C-2", O-C-4-C-4a-C-1' and C-4-C-4a-C-1'-C-2' and optimized using the semi-empirical $\mathrm{PM6}^{11}$ method available in the Gaussian 09 program. ${ }^{12}$ Re-optimization of DFT at the B3LYP/6-31G (d) level of theory ${ }^{13-16}$ in $\mathrm{MeOH}$ solvent simulated using the polarizable continuum model $\left(\mathrm{PCM}^{17}\right)$ yielded seven conformers. ${ }^{18,19}$ The three low-energy (Boltzmann distribution $>1 \%$ ) conformers contributed $98.2 \%$ of the Boltzmann distribution. Further optimization of these conformers at B3LYP/6-31++G $(\mathrm{d}, \mathrm{p})$ level and Excitation energies, rotatory strengths, and oscillator strengths for each transition were calculated for the first 40 electronic states at the same level.

ECD spectra were simulated by overlapping Gaussian functions for each transition formulated as:

$\Delta \varepsilon(\tilde{v})=\frac{1}{\left(2.296 \times 10^{-39}\right) \sigma \sqrt{\pi}} \sum_{i=1}^{n} \tilde{v}_{i} R_{i} \exp \left[-\left(\frac{\tilde{v}-\tilde{v}_{i}}{\sigma}\right)^{2}\right]$

where $\tilde{v}$ is the central wavenumber of the Cotton effect, $\sigma$ is half the bandwidth at $1 / e$ peak height, and $\tilde{v}_{i}$ and $R_{i}$ are the excitation energy (in wavenumber) and rotatory strength for transition $i$, respectively. The $\sigma$ value was evaluated from the corresponding UV spectrum, and a value of $0.32 \mathrm{eV}$ was chosen. The total ECD spectrum was obtained according to the Boltzmann-averaged contribution of each conformer.

Biological activities Assessment Tyrosinase inhibitory activity, $\alpha$-glucosidase inhibitory activity and DPPH radical scavenging activity were evaluated according to previously reported methods with minor modification. $^{20-22}$

\section{REFERENCES}

1. 'Chuyaku Daijiten', 1st edn., Shanghai Science-Technology Publishing Co. and Shogakukan Inc., Vol. 1, Shogakukan Inc., Tokyo, 1985, pp. 195-197.

2. H. Ishida, T. Umino, K. Tsuji, and T. Kosugi, Chem. Pharm. Bull., 1989, 37, 1616.

3. S. Shibata and Y. Nishikawa, Chem. Pharm. Bull., 1963, 11, 167.

4. M. Komatsu, I. Yokoe, and Y. Shirataki, Yakugaku Zasshi, 1976, 96, 254. 
5. Y. Shirataki, Y. Tagaya, I. Yokoe, and M. Komatsu, Chem. Pharm. Bull., 1987, 35, 1637.

6. T. Nohara, J. Kinjo, J. Furusawa, Y. Sakai, M. Inoue, Y. Shirataki, Y. Ishibashi, Y. Yokoe, and M. Komatsu, Phytochemistry, 1993, 33, 1207.

7. M. H. Hwang, Y. S. Kwon, and C. M. Kin, Natural Medicines, 1998, 52, 527.

8. S. Kobayashi, T. Miyase, and H. Noguchi, J. Nat. Prod., 2002, 65, 319.

9. J. Kinjo, J. Furusawa, and T. Nohara, Terahedron Lett., 1985, 26, 6101.

10. T. Tanaka, T. Nakashima, T. Ueda, K. Tomii, I. Kouno, and Y. Nishikawa, Chem. Pharm. Bull., 2007, 55, 899 .

11. J. J. P. Stewart, J. Mol. Model., 2007, 13, 1173.

12. M. J. Frisch, G. W. Trucks, H. B. Schlegel, G. E. Scuseria, M. A. Robb, J. R. Cheeseman, G. Scalmani, V. Barone, B. Mennucci, G. A. Petersson, H. Nakatsuji, M. Caricato, X. Li, H. P. Hratchian, A. F. Izmaylov, J. Bloino, G. Zheng, J. L. Sonnenberg, M. Hada, M. Ehara, K. Toyota, R. Fukuda, J. Hasegawa, M. Ishida, T. Nakajima, Y. Honda, O. Kitao, H. Nakai, T. Vreven, J. A. Montgomery, J. E. Peralta, F. Ogliaro, M. J. Bearpark, J. Heyd, E. N. Brothers, K. N. Kudin, V. N. Staroverov, R. Kobayashi, J. Normand, K. Raghavachari, A. P. Rendell, J. C. Burant, S. S. Iyengar, J. Tomasi, M. Cossi, N. Rega, N. J. Millam, M. Klene, J. E. Knox, J. B. Cross, V. Bakken, C. Adamo, J. Jaramillo, R. Gomperts, R. E. Stratmann, O. Yazyev, A. J. Austin, R. Cammi, C. Pomelli, J. W. Ochterski, R. L. Martin, K. Morokuma, V. G. Zakrzewski, G. A. Voth, P. Salvador, J. J. Dannenberg, S. Dapprich, A. D. Daniels, Ö. Farkas, J. B. Foresman, J. V. Ortiz, J. Cioslowski, and D. J. Fox, Gaussian 09; Gaussian, Inc.: Wallingford, CT, USA, 2013.

13. A. D. Becke, J. Chem. Phys., 1993, 98, 5648.

14. C. Lee, W. Yang, and R. G. Parr, Phys. Rev. B, 1988, 37, 785.

15. B. Miehlich, A. Savin, H. Stoll, and H. Preuss, Chem. Phys. Lett., 1989, 157, 200.

16. P. J. Stephens, F. J. Devlin, C. F. Chabalowski, and M. J. Frisch, J. Phys. Chem., 1994, 98, 11623.

17. S. Miertuš, E. Scrocco, and J. Tomasi, Chem. Phys., 1981, 55, 117.

18. K. L. Bak, A. E. Hansen, K. Ruud, T. Helgaker, J. Olsen, and P. Jorgensen, Theor. Chim. Acta, 1995, 90, 441.

19. J. Autschbach, T. Ziegler, S. J. A. van Gisbergen, and E. J. Baerends, J. Chem. Phys., 2002, 116, 6930.

20. Y. N. Huang, Y. L. Zhao, X. L. Gao, Z. F. Zhao, Z. Jing, W. C. Zeng, R. Yang, R. Peng, T. Tong, L. F. Wang, J. Q. Cen, and H. Gao, J. Ethnopharmacol., 2010, 131, 306.

21. K. Takao, K. Toda, T. Saito, and Y. Sugita, Chem. Pharm. Bull., 2017, 65, 1020.

22. K. Yamauchi, T. Mitsunaga, and I. Batubara, Nat. Resour., 2011, 02, 167. 